http://jmscr.igmpublication.org/home/ ISSN (e)-2347-176x ISSN (p) 2455-0450 crossref DOI: https://dx.doi.org/10.18535/jmscr/v8i1.34

\title{
Histomorphological study of cervical lesions in a tertiary care Centre of kumaon region: A 5 year retrospective study
}

\author{
Authors \\ Dr Bhagyashree ${ }^{1}$, Dr Usha Joshi ${ }^{2 *}$, Dr Ankit Kaushik ${ }^{3}$ \\ ${ }^{1}$ Junior Resident, ${ }^{2}$ Associate Professor, ${ }^{3}$ Assistant Professor \\ Department of Pathology, Government Medical College Haldwani \\ *Corresponding Author \\ Dr Usha Joshi \\ Associate Professor, Department of Pathology, Government Medical College Haldwani, India
}

Abstract
Introduction: Non- neoplastic and neoplastic cervical lesions are seen among women of all age groups
but are more common in sexually active women. In developing countries, there is a lack of effective
screening programs and vaccination due to which there is increased risk of cervical cancer.
Methods: A retrospective histopathological analysis of 690 cases of cervical lesions were undertaken in
the department of pathology over a period of 5 year at Government Medical College haldwani,
Uttarakhand.
Results: Out of 690 cases, Non-neoplastic lesion were seen in 570 cases ( $82.4 \%)$ while neoplastic lesion
were seen in 120 cases (17.6\%). The most commonly affected age group was $41-50$ yr. Among non-
neoplastic lesion most common histological finding was chronic cervicitis in premenopausal age group
and squamous metaplasia in postmenopausal age group. Among neoplastic lesion, non-Keratinising
squamous cell carcinoma was the most common finding in both premenopausal and postmenopausal age
group followed by keratinising squamous cell carcinoma.
Keywords: Cervicitis, Squamous metaplasia.

\section{Introduction}

Non- neoplastic and neoplastic cervical lesions are seen among women of all age groups but are more common in sexually active women. Majority of non- neoplastic lesions are inflammatory in nature. ${ }^{[1]}$

In the urban areas, cancer of cervix accounts for $40 \%$ of cancer while in rural areas, it accounts for $65 \%$ of cancer due to inaccessibility of health care services and financial insufficiency in rural areas. ${ }^{[2]}$ The incidence of cervical cancer rises in 30-34 years of age and peaks at 55-65 years especially from lower socioeconomic status. ${ }^{[3]}$
Human Papillomavirus (HPV) being the most common cause of cervical cancer affecting women of different age groups and has a prevalence of about $20 \%$ in young sexually active women. ${ }^{[4]}$

In developing countries, there is a lack of HPV vaccination and effective screening programs for cervical cancer. Limited success of such screening programmes in developing countries had led to increased risk of cervical cancer. Whereas, in developed countries due to introduction of largescale cytologic testing there has been a major decline in cervical-cancer mortality. 
The aim of the present study is to evaluate frequency of non-neoplastic and neoplastic cervical lesion in kumaon region. So, that cervical screening programmes in this region for early detection of malignancy can be carried out.

\section{Materials and Methods}

A retrospective histopathological analysis of 690 cases of cervical lesions was undertaken in the department of pathology over a period of 5 year at Government Medical College haldwani, Uttarakhand. The material for the study consists of both cervical punch biopsy and cervix from hysterectomy specimens. Specimens were sent to the pathology department for histopathological examination in 10 percent formalin. They were studied grossly and multiple sections taken. The specimens were processed in automated tissue processor. Four to six-micron thick paraffin embedded sections were taken and stained by haematoxylin and eosin. The slides were then examined and reported.

\section{Results}

In this 5year study, a total 690 cases of nonneoplastic and neoplastic lesions from cervical specimens were analysed. The age of patient in this study ranges from 21-90 years with maximum number of cases in age group 41 to 50 years (Table 1). Of the 690 cases, non-neoplastic lesions constituted $82.4 \%$ (570 cases) and neoplastic lesion constituted $17.6 \%$ (120 cases). Non neoplastic lesions were more common in the age group of 41-50 yr (46\%) (Table 2). Among nonneoplastic lesion most common histological finding was chronic cervicitis in premenopausal age group and squamous metaplasia in postmenopausal age group (Table4).

Among neoplastic lesions most common age group affected was 41-50 yr (30\%). NonKeratinising squamous cell carcinoma was the most common finding in both premenopausal and postmenopausal age group followed by keratinising squamous cell carcinoma. While high-grade dysplasia was seen in all age group included in our study, 10 cases of cervical polyp, one case of cervical fibroid and one case of angiokeratoma was seen in 41-50 yrs of age. One case each of transitional squamous cell carcinoma, papillary squamous cell carcinoma, adenocarcinoma with squamoid differentiation and poorly differentiated carcinoma was seen among postmenopausal age group. In our study, one rare case of cavernous hemangioma was also seen in age group 21- $30 \mathrm{yr}$. (Table 5)

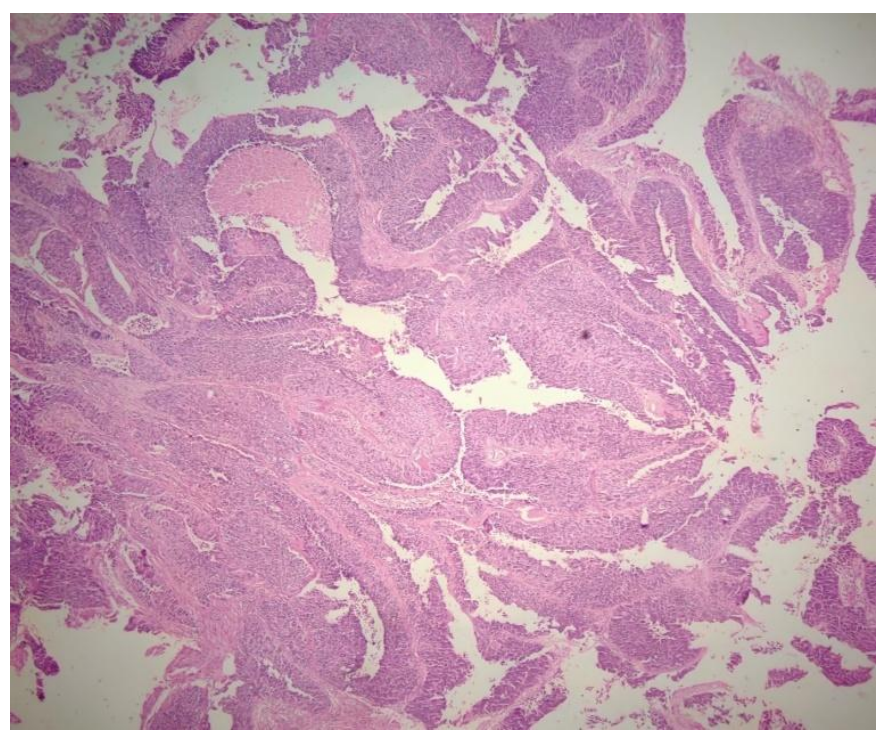

Caption 1: Papillary squamous cell carcinoma showing finger like projections with fibrovascular cores. Overlying squamous epithelium is malignant. (H\&E 10X)

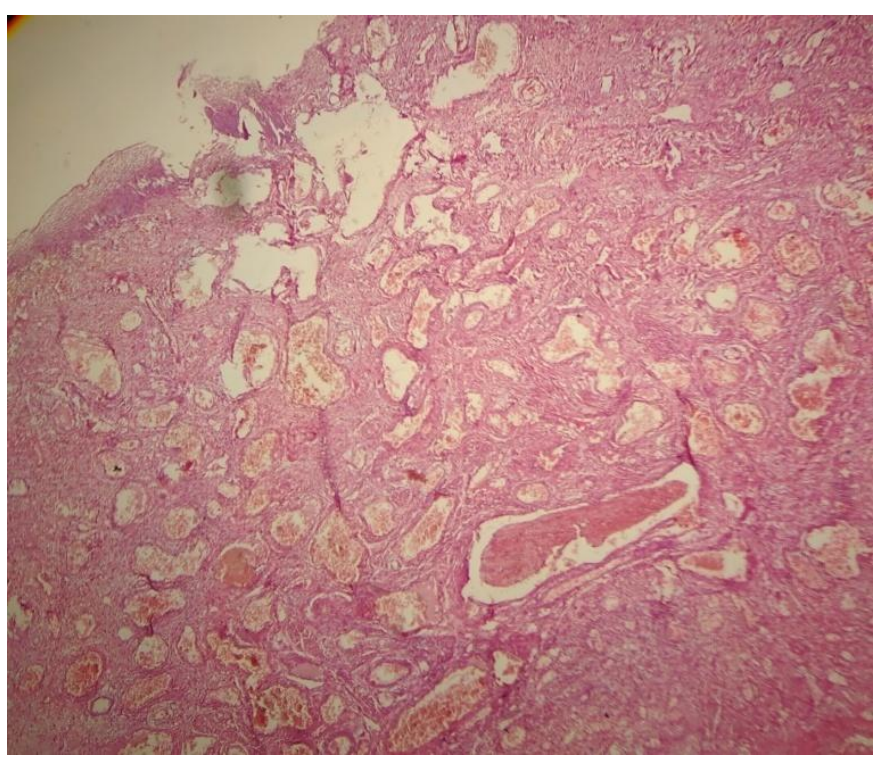

Caption 2: Cavernous hemangioma: shows large cystically dilated vessels with thin walls. (H\&E 10X) 
Table 1: Distribution of cases among different age group

\begin{tabular}{|l|c|}
\hline AGE (YEARS) & NO. OF CASES (N=690) \\
\hline $21-30$ & $18(2 \%)$ \\
\hline $31-40$ & $171(25 \%)$ \\
\hline $41-50$ & $299(43 \%)$ \\
\hline $51-60$ & $122(18 \%)$ \\
\hline $61-70$ & $53(8 \%)$ \\
\hline $71-80$ & $22(3 \%)$ \\
\hline $81-90$ & $5(1 \%)$ \\
\hline
\end{tabular}

Table 2: Distribution of non - neoplastic and neoplastic lesion among different age group.

\begin{tabular}{|l|c|c|}
\hline $\begin{array}{l}\text { AGE } \\
\text { (YEARS) }\end{array}$ & $\begin{array}{c}\text { NON- } \\
\text { NEOPLASTIC }\end{array}$ & NEOPLASTIC \\
\hline $21-30$ & $15(2 \%)$ & $3(2 \%)$ \\
\hline $31-40$ & $150(26 \%)$ & $21(17 \%)$ \\
\hline $41-50$ & $263(46 \%)$ & $36(30 \%)$ \\
\hline $51-60$ & $90(16 \%)$ & $32(27 \%)$ \\
\hline $61-70$ & $38(7 \%)$ & $15(13 \%)$ \\
\hline $71-80$ & $11(2 \%)$ & $11(9 \%)$ \\
\hline $81-90$ & $3(1 \%)$ & $2(2 \%)$ \\
\hline TOTAL & 570 & 120 \\
\hline
\end{tabular}

Table 3: Distribution of Cervical Lesions.

\begin{tabular}{|l|l|c|}
\hline S.no. & Diagnosis & No.of cases \\
\hline 1. & Chronic cervicitis & 285 \\
\hline 2. & Squamous metaplasia & 283 \\
\hline 3. & Cavernous hemangioma & 1 \\
\hline 4. & Angiokeratoma cell & 19 \\
\hline 5. & Cervical polyp & 15 \\
\hline 6. & High grade dysplasia squamous cell & 54 \\
\hline 7. & $\begin{array}{l}\text { Keratinizing squamous cell } \\
\text { carcinoma } \\
\text { carcinoma }\end{array}$ & 1 \\
\hline 9. & $\begin{array}{l}\text { Transitional squamous cell } \\
\text { carcinoma }\end{array}$ & 2 \\
\hline 10. & $\begin{array}{l}\text { Papillary squamous } \\
\text { carcinoma }\end{array}$ & 1 \\
\hline 11. & $\begin{array}{l}\text { Adenocarcinoma with squang } \\
\text { differentiation }\end{array}$ & 1 \\
\hline 12. & Poorly differentiated carcinoma & 1 \\
\hline
\end{tabular}

Table 4: Age Distribution of Non- Neoplastic Cervical Lesions

\begin{tabular}{|l|c|c|c|c|c|c|c|}
\hline Diagnosis & 21-30YR & 31-40YR & 41-50YR & 51-60YR & 61-70YR & 71-80YR & 81-90YR \\
\hline Chronic cervicitis & 9 & 72 & 136 & 44 & 18 & 4 & 2 \\
\hline Squamous metaplasia & 5 & 78 & 126 & 46 & 20 & 7 & 1 \\
\hline
\end{tabular}

Table 5: Age Distribution of Neoplastic Cervical Lesions.

\begin{tabular}{|c|c|c|c|c|c|c|c|}
\hline Diagnosis & 21-30YR & 31-40YR & 41-50YR & 51-60YR & 61-70YR & 71-80YR & 81-90YR \\
\hline Cervical polyp & - & 3 & 10 & 4 & 1 & 1 & - \\
\hline High grade dysplasia & 1 & 3 & 3 & 4 & 5 & - & - \\
\hline $\begin{array}{l}\text { Keratinizing } \\
\text { carcinoma }\end{array}$ & & 6 & 7 & 6 & 3 & 5 & \\
\hline $\begin{array}{l}\text { Non-Keratinizing squamous cell } \\
\text { carcinoma }\end{array}$ & 2 & 8 & 15 & 17 & 7 & 4 & 1 \\
\hline $\begin{array}{l}\text { Transitional squamous } \\
\text { carcinoma }\end{array}$ & - & - & 1 & - & - & - & - \\
\hline $\begin{array}{lll}\begin{array}{l}\text { Papillary } \\
\text { carcinoma }\end{array} & \text { squamous } & \text { cell } \\
\end{array}$ & - & 1 & - & 1 & - & - & - \\
\hline $\begin{array}{l}\text { Adenocarcinoma with squamous } \\
\text { differentiation }\end{array}$ & - & - & - & - & - & - & 1 \\
\hline Poorly differentiated carcinoma & - & - & - & - & - & 1 & - \\
\hline Cavernous hemangioma & 1 & & & & & & \\
\hline Angiokeratoma & & & 1 & & & & \\
\hline
\end{tabular}

\section{Discussion}

Out of 690 cases, $570(82.6 \%)$ cases were benign and $120(17.4 \%)$ cases were malignant lesions. The ratio of benign to malignant accounted for 4.7:1. This result clearly shows that benign lesions were more common than their malignant counterparts in kumaon region which is similar to study done by Ozumba et al. where benign lesions were more common than malignant lesions. ${ }^{[4,5]}$
The peak age range of non- neoplastic cervical lesions was 41- 50 years accounting for $43 \%$. This finding is similar to previous reports from Kumar et al and Poste et al ${ }^{[6,7]}$ where peak age of 40- 49 years accounted for $76.7 \%$. Our findings have shown that among the non- neoplastic cervical lesions, $41.3 \%$ were associated with features of cervicitis. Thus, it constitutes the highest percentage of non- neoplastic cervical 
lesions in our region. This report again is similar to previous studies done by Poste el and Nwachokor et al where cervicitis accounted for $38 \%$ and $59.8 \%$ respectively. ${ }^{[7,1]}$ As major population included in this study is from Kumaoni hilly area, therefore, lack of awareness, cultural barriers, economic factors limitations of kumaoniwomens in obtaining health services and also expressing their needs for reproductive health leads to increase risk of chronic cervicitis from early age group.

Chronic nonspecific cervicitis with squamous metaplasia was found in 126 cases in this study in the age group of 41-50 years (Table no.3), which is contrary to the study done by Jyothi et al in which $30-40 y r$ age group was the most common. ${ }^{[8]}$ Due to high risk factors like early child marriage, multigravida status, early age at first pregnancy in this socioeconomic class of women results into further progression of disease leading to squamous metaplasia.

Our findings showed that endocervical polyps accounted for $2.7 \%$ of non- neoplastic cervical lesions and the peak age range was in the 4th decade. This is similar to study done by Pallipady et al, Jones et al and Nigatu et al where cervical polyps were more commonly seen in the reproductive age especially after 40 years of age. $[9,10,11]$

High grade dysplasia was seen in the age group of 21-70 yr which accounted for 2.2\%(15cases). As the disease is following its natural course leading to high grade dysplasia so awareness to cervical screening programme from early age group becomes necessary to prevent early onset of disease.

In this study, squamous-cell carcinoma was the predominant histological type of cervical malignancy constituting $12.4 \%$ (86 cases) and the incidence was highest in the age group of

51-80 years which is contrary to study done by Reddy et al in which most common age group was $41-60 \mathrm{yr}^{[12]}$. High risk of cancer in later age group among kumaoniwomens is due to lack of both awareness about the disease and access to prevention and treatment facilities.

In rural population, reliance on indigenous cures and traditional reluctance among many females to seek medical assistance from a gynaecologist had also heighten womens vulnerability to infection and progression of disease to cancer. Even pap smear programs have proved to be difficult to implement and costly to run in rural areas due to which cases of unhealthy cervix is increasing in this region.

\section{Sources of support in the form of grants -No grants taken.}

\section{Reference}

1. Forae G, Nwachokor F. Morphological spectrum of non-neoplastic lesions of the uterine cervix in Warri, South-South, Nigeria. Niger J Clin Pract. 2013;16(4):429.

2. Mukesh S, Arul Ponni T, Nirmala S, Janaki M. Aggressive approach in a case of cancer cervix with uremia. Indian $\mathbf{J}$ Palliat Care. 2010;16(1):52.

3. Bagde S, Gupta R, Ganguly S, Bhardwaj A, Jogi S. SPECTRUM OF CERVICAL LESIONS IN CIMS, BILASPUR: A 5 YEAR RETROSPECTIVE STUDY OF 215 CASES IN A TERTIARY HOSPITAL OF CENTRAL INDIA. jebmh. 2015 Oct 19;2(42):7505-10.

4. Faridi R, Zahra A, Khan K, Idrees M. Oncogenic potential of Human Papillomavirus (HPV) and its relation with cervical cancer. Virol J. 2011;8(1):269.

5. Keshinro SO, Nwafor CC, Oshun $\mathrm{P}$. HISTOLOGIC ANALYSIS OF GYNAECOLOGIC LESIONS IN NIGERIANS. East African Medical Journal. 2015;8.

6. Rajendiran S, Gopalan U, Karnaboopathy R. Evaluation of histopathology of cervix in women with unhealthy cervix. Int $\mathrm{J}$ 
Reprod Contracept Obstet Gynecol. 2017 Feb 19;6(3):842.

7. Clinico-Pathological Study of NonNeoplastic Lesions of Uterine Cervix with their Histopathological Categorization. 2013;4(2):5.

8. Poste P, Patil A, Andola SK. Incidence of Non-Neoplastic Cervical Pathologies Recorded at a Medical College. :12.

9. Pallipady A, Illanthody S, Vaidya R, Ahmed Z, Suvarna R, Metkar G. A Clinico-Morphological Spectrum of the Non Neoplastic Lesions of the Uterine Cervix at AJ Hospital, Mangalore. Journal of Clinical and Diagnostic Research. 2011;5:5.

10. Jones MA, Young RH. Atypical oxyphilic metaplasia of the endocervical epithelium: a report of six cases. Int J GynecolPathol. 1997 Apr;16(2):99-102.

11. D P, AArathiC. Histopathological Spectrum of Non-Neoplastic Uterine Cervical Lesions in a Tertiary Care Centre. APALM. 2017 May 28;4(3):A303-9.

12. Reddy S, Rani M, Rao K. Clinicohistopathologic study of nonneoplastic uterine cervical lesions. Int J Med Sci Public Health. 2016;5(8):1536. 